\title{
Corporate Reputation of the Schools and Faculties of Social Work around Training by Competences of Intellectual Capital
}

\section{Javier Carreón-Guillén ${ }^{1}$, Tirso Javier Hernández-Gracia ${ }^{2}$, Arturo Sánchez-Sánchez ${ }^{3}$, Francisco Espinosa-Morales ${ }^{4}$, Eréndira Fierro- Moreno $^{5}$, Sonia Sujell Velez-Baez ${ }^{6}$, Francisco Rubén Sandoval-Vázquez ${ }^{7}$ and Cruz García-Lirios ${ }^{8 *}$}

${ }^{1}$ National Autonomous University of Mexico, Mexico

${ }^{2}$ Autonomous University of the State of Hidalgo, Mexico

${ }^{3}$ Autonomous University of Tlaxcala, Mexico

${ }^{4}$ University of Sonora, Mexico

${ }^{5}$ Autonomous University of the State of Mexico, Mexico

${ }^{6}$ Autonomous University of Queretaro, Mexico

${ }^{7}$ Autonomous University of the State of Morelos, Mexico

${ }^{8}$ Autonomous Metropolitan University, Mexico

${ }^{\star}$ Corresponding author: Cruz García-Lirios, Autonomous Metropolitan University, Mexico; Email: csh96327267@titlani.uam.mx

Received: February 16, 2022; Accepted: February 21, 2022; Published: February 22, 2022

\begin{abstract}
Corporate governance as a knowledge management system has been approached from the organizational reputation as a result of alliances with institutions. In the health sector, the demand for quality service has led to a system of professional internships and deregulated social service in which the image of the universities and health centers involved is in question. The objective of the present work was to contrast a model for the study of the phenomenon with the intention of specifying the relationships between variables. A non-experimental, exploratory and cross-sectional study was carried out with a non-probabilistic and intentional sample of 1018 administrators, professionals and students from the health sector. It was found that the case monitoring factor reflected the image of universities as trainers of intellectual capital by competencies. In relation to the consulted literature, lines of research are proposed to specify the model.
\end{abstract}

Keywords: Corporation, Training, Reputation, Competencies, Responsibility

\section{Introduction}

Within the framework of human development, health is a fundamental item for observing the corporate reputation of the School and Faculties of Social Work, understanding that it is about expectations of users, administrators, professionals and students regarding the quality of service public and depending on spending on prevention and care [1].

Mexico occupies the third last place in terms of health, public, social works, prepayments, out-of-pocket expenses, among other items related to prevention and care, which add up to $6 \%$ of the Gross Domestic Product (GDP) [2].

The corporate reputation of Public Health Institutions (ISP) and Higher Education Institutions (HEI) can be established if spending is associated with user expectations [3]. The 2015 economic census and the survey on the quality of public services note a medium and low performance of public centers and hospitals [4].

The average expenditure on medications and medical consultation is in second place once food and personal hydration have been paid for [5].

If it is considered that spending on hydration accounts for $20 \%$ of income for the popular, marginalized and excluded sectors, the prevention of diseases transmitted by hydration, when associated with spending on professional medical care, as well as on medicines, accounts for $40 \%$ for areas peri-urban areas from where they move to central cities to work, study or seek employment and education opportunities [6].

Regarding the formation of intellectual capital, Mexico occupies the penultimate place in the OECD in terms of adolescents and young people who do not have access to study or work, which is added to $14 \%$ of expectations of low quality of public education [6].

It is possible to infer that the reputation of corporate governance, health and medical assistance institutions, as well as the formation of intellectual capital, are on the decline, and a diagnosis of the HEIs that train health professionals is urgent, among which are the Schools and Faculties of Social Work [7]. 


\section{Corporate Reputation Theory}

Figure 1 shows the theoretical and conceptual frameworks that explain corporate reputation understood as the expectations of employees, directors and clients alluding to effective responses to environmental contingencies, context requirements or social demands [8].

The Stakeholders Theory warns that employees, shareholders, leaders and clients not only have a direct and significant participation in the company but also confront peripheral actors such as protesters, the media or institutions that seek to counteract the prestige of the company. institution in order to increase its credibility and position itself in the market [9].

Around the conflict between the interested parties and external factors to public health institutions, corporate governance is created as a shield of empathy, trust, commitment and satisfaction that guarantees the union of shareholders, leaders, employees and clients against the environmental threats, but it is in terms of reputation and prestige that differences and similarities between internal and external actors are resolved [10].

However, it is known that adhocratic organizational cultures, as well as traditional leadership, promote internal asymmetries in the face of external threats to the detriment of corporate reputation and prestige [11].

It will be the transforming cultures and leaderships who will manage knowledge to establish competitive advantages in the formation of intangible assets such as training and training of intellectual capital, future artificial and emotional intelligence cadres that will be decisive in entrepreneurship and innovation [12].

In such a context and scenario of cultures and transformative leaderships, decision makers are oriented towards vision and prospective missions as a second competitive advantage coupled with the formation of intangible assets [13].

This is the case of strategic alliances and knowledge management between HEIs and community, public or collective health institutions where systems of professional practices and social service are established in order to train future health professionals, among whom are social workers [14].

The Theory of Prospective Decisions posits that organizations prefer intentions and decisions aimed at maximizing risks and profits

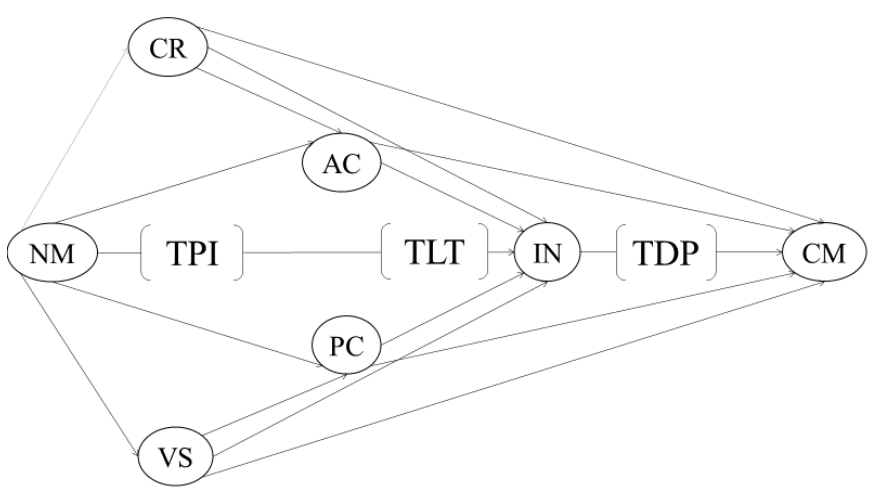

Figure 1: Corporate Reputation Theory over strategies to reduce risks and reduce benefits [15].

In the case of the formation of human capital, a prospective decision suggests risks in the formation with high benefits in the prestige and reputation of the HEI or the health center. These are early professional internship strategies for students who have not covered the minimum credits, or social services who have not accredited seminars or basic subjects [16].

Another aspect to consider refers to the lack of resources for the hiring of professionals and the employment of interns and social workers to remedy the deficit of attention to public health services, or their use in health promotion, campaigns of prevention or allocation of medications to vulnerable groups [17].

In sum, stakeholder theory, transformational leadership theory, and prospective decision theory suggest the need for a comprehensive, specific, and up-to-date diagnosis of corporate governance, reputation, and institutional prestige, as well as expectations. of shareholders, directors, talents and users of HEIs in strategic alliances with collective health centers [18].

Given that corporate governance in general and training reputation and prestige in particular are little studied objects in the HEIs where the Schools and Faculties of Social Work are located, it is necessary to carry out a comprehensive diagnosis of the skills of future professionals with the purpose of inferring the intangible value of public universities in strategic alliances with health centers, as well as their differences and similarities in terms of professional skills [19].

\section{Formulation}

Will there be significant differences between HEIs in central, western and northern Mexico in terms of training skills for health services?

\section{Hypothesis}

\section{Null Hypothesis}

There will be significant differences between the HEIs studied with respect to the professional training of skills for public health services

\section{Alternate Hypothesis}

There will be no significant differences between the study HEIs regarding the professional training of skills for public health services

\section{Method}

An exploratory study was carried out with a sample of students, directors and professionals of the Social Work of Health in HEIs in the center, west and northeast of Mexico, considering their affiliation to a public university with an internship system in health centers, accreditation of the minimum percentage for social service and professional practices (Table 1).

The Corporate Reputation Scale (ERC-28) was built based on items selected from the consulted literature, which measured expectations of the parties involved regarding objectives, tasks and goals related to entrepreneurial and innovative knowledge skills such as collaborative work. professional (Table 2). 
Table 1: Descriptions of the study sample.

\begin{tabular}{|l|c|c|c|c|c|c|}
\hline & Students & professionals & Administrative & Sex & Age & Entry \\
\hline UAEH & 93 & 37 & 14 & Female (45\%) Male (55\% & $\mathrm{M}=25.3 \mathrm{SD}=3.89$ & $\mathrm{M}=\$ 346.1 \mathrm{SD}=\$ 9.3$ \\
\hline UAEM & 91 & 3.4 & 12 & Female $(57 \%)$ Male $(43 \%)$ & $\mathrm{M}=29.8 \mathrm{SD}=4.78$ & $\mathrm{M}=342.1 \mathrm{DE}=\$ 8.3$ \\
\hline UAEMEX & 90 & 33 & eleven & Female $(67 \%)$ Male $(33 \%)$ & $\mathrm{M}=27.3 \mathrm{SD}=3.80$ & $\mathrm{M}=\$ 432.1 \mathrm{SD}=\$ 7.1$ \\
\hline UAM & 89 & 30 & 10 & Female $(49 \%)$ Male $(51 \%)$ & $\mathrm{M}=28.6 \mathrm{SD}=2.79$ & $\mathrm{M}=367.2 \mathrm{DE}=\$ 8.2$ \\
\hline UAQ & 87 & 29 & 9 & Female $(44 \%)$ Male $(56 \%)$ & $\mathrm{M}=36.1 \mathrm{SD}=1.32$ & $\mathrm{M}=\$ 342.1 \mathrm{SD}=9.3$ \\
\hline UAT & 85 & 27 & 8 & Female $(52 \%)$ Male $(48 \%)$ & $\mathrm{M}=33.1 \mathrm{SD}=1.67$ & $\mathrm{M}=\$ 396.1 \mathrm{SD}=\$ 10.4$ \\
\hline UNAM & 84 & 25 & 7 & Female $(43 \%)$ Male $(57 \%)$ & $\mathrm{M}=37.1 \mathrm{SD}=4.35$ & $\mathrm{M}=\$ 354.1 \mathrm{SD}=71.1$ \\
\hline USON & 83 & 24 & 6 & Female $(60 \%)$ Male $(40 \%)$ & $\mathrm{M}=39.8 \mathrm{SD}=2.34$ & $\mathrm{M}=\$ 359.8 \mathrm{SD}=\$ 5.4$ \\
\hline
\end{tabular}

Source: Prepared with study data.

Table 2: Construction of the ERC-28.

\begin{tabular}{|c|c|c|c|c|}
\hline Competence & Definition & Indicator & Coding & Interpretation \\
\hline Accompaniment & $\begin{array}{c}\text { It refers to an emotional ability to establish a bond } \\
\text { of social, family or personal support with the user } \\
\text { of the health service (Vaquero, 2012) }\end{array}$ & $\begin{array}{c}\text { Data relating to cases of self-medication } \\
\text { or self-harm }\end{array}$ & $\begin{array}{l}0=\text { "not at all likely" } \\
\text { to } 5=\text { ="quite likely" }\end{array}$ & $\begin{array}{c}\text { High scores refer to a corporate governance } \\
\text { focused on the reputation and professional training } \\
\text { prestige of the accompaniment }\end{array}$ \\
\hline Accession & $\begin{array}{l}\text { It refers to the ability to motivate the user to } \\
\text { use the health service in terms of consultation } \\
\text { requests, medications and advice. (Kolade, } \\
\text { Olakkeke, \& Omotayo, 2014) }\end{array}$ & $\begin{array}{l}\text { (Data referring to the cases of } \\
\text { rehabilitation and desertion to treatments }\end{array}$ & $\begin{array}{l}0=\text { "not at all likely" } \\
\text { to } 5=\text { "quite likely" }\end{array}$ & $\begin{array}{c}\text { High scores refer to a corporate governance } \\
\text { focused on the reputation and professional training } \\
\text { prestige of adherence to treatment }\end{array}$ \\
\hline Advisory & $\begin{array}{c}\text { It refers to an ability to establish effective and } \\
\text { accessible processing routes for health service } \\
\text { users (Rondeaeu, 2017) }\end{array}$ & $\begin{array}{l}\text { Data alluding to the time of delay in each } \\
\text { of the phases of the health service from } \\
\text { the request for care to the rehabilitation }\end{array}$ & $\begin{array}{l}0=\text { "not at all likely" } \\
\text { to } 5=\text { ="quite likely" }\end{array}$ & $\begin{array}{c}\text { High scores refer to a corporate governance } \\
\text { focused on the reputation and professional training } \\
\text { prestige of the management consultancy }\end{array}$ \\
\hline Interview & $\begin{array}{c}\text { It refers to an ability to establish empathy with the } \\
\text { user of health services, their needs, shortcomings } \\
\text { and opportunities for a risk-free life (Olajide, } \\
\text { 2014) }\end{array}$ & $\begin{array}{c}\text { Data alluding to the user's detachment } \\
\text { and trust towards health professionals, } \\
\text { bureaucracy and administrative } \\
\text { managers }\end{array}$ & $\begin{array}{l}0=\text { "not at all likely" } \\
\text { to } 5=\text { "quite likely" }\end{array}$ & $\begin{array}{c}\text { High scores refer to a corporate governance } \\
\text { focused on the reputation and professional training } \\
\text { prestige of the diagnostic interview }\end{array}$ \\
\hline Mediation & $\begin{array}{l}\text { It refers to an ability to reduce differences } \\
\text { and conflicts, as well as to establish points of } \\
\text { agreement between the parties (Kelinde, 2012). }\end{array}$ & Data related to conflicts and conciliations & $\begin{array}{l}0=\text { "not at all likely" } \\
\text { to } 5=\text { "quite likely" }\end{array}$ & $\begin{array}{c}\text { High scores refer to a corporate governance } \\
\text { focused on the reputation and professional training } \\
\text { prestige of conflict mediation }\end{array}$ \\
\hline Promotion & $\begin{array}{l}\text { It refers to an ability to disseminate data and } \\
\text { prevention strategies for illnesses and accidents } \\
\text { for a risk-free life (Jinfeng, Runtian, \& Quian, } \\
\text { 2014). }\end{array}$ & $\begin{array}{l}\text { Data alluding to illnesses and accidents } \\
\text { that affect occupational, emotional or } \\
\text { biophysical health }\end{array}$ & $\begin{array}{l}0=\text { "not at all likely" } \\
\text { to } 5=\text { =quite likely" }\end{array}$ & $\begin{array}{c}\text { High scores refer to a corporate governance } \\
\text { focused on the professional training reputation and } \\
\text { prestige of health promotion }\end{array}$ \\
\hline Follow-up & $\begin{array}{l}\text { It refers to an ability to establish parameters of } \\
\text { quality of care in terms of satisfaction of the user } \\
\text { of the health service (Melero and López, 2017) }\end{array}$ & $\begin{array}{l}\text { Data alluding to the quality of care and } \\
\text { customer satisfaction }\end{array}$ & $\begin{array}{l}0=\text { "not at all likely" } \\
\text { to } 5=\text { "quite likely" }\end{array}$ & $\begin{array}{c}\text { High scores refer to a corporate governance } \\
\text { focused on the reputation and professional training } \\
\text { prestige of case monitoring }\end{array}$ \\
\hline
\end{tabular}

Source: Self made.

The surveys were carried out in the facilities of the HEIs and health centers with a prior written guarantee of confidentiality, anonymity and non-affectation of the results. The information was processed in the Statistical Package for Social Sciences (SPSS version 25.0).

Reliability and validity analyzes of the instrument, hypothesis tests for differences between groups, as well as correlations, general linear models and structural equation models were carried out to establish the trajectories of dependency relationships between the variables and indicators of the ERC-15.

The following parameters were estimated: 1) mean, 2) standard deviation, 3) bias, 4) kurtosis, 5) asymmetry, 6) Crombach 's alpha , 7) Student's t - test, 8) analysis of variance F-test, 9) KMO test, 10) Bartlett test, 11) Pearson correlations, 12) beta regressions, 13) goodness of fit, and 14) residuals.

\section{Results}

Table 3 shows the statistical properties of the ERC-28 in which reliability alpha values higher than the indispensable minimum of .700 are observed for the general instrument (alpha of .780) and the subscales (respective alphas of .776; .781); .756; .790; .719; .750; .732).
The correlation matrix shows discriminant validity by including values close to zero, but the covariance matrix warns of the possibility of excluding other factors due to values close to unity (Table 4).

The sum of the percentages of explained variance (87\%) revealed the preponderance of seven factors that can converge in a common factor of the second order (Figure 2).

The second-order factor related to corporate reputation included the eight first-order factors established from the review of the literature. The structural model included as a reflective factor the competence of case follow-up (.67). In other words, the corporate reputation of the social work public service is centered on the academic and administrative training of monitoring skills rather than on the skills of support, adherence, advice, interview, mediation and health promotion.

The fit and residual parameters $\left[\mathrm{X}^{2}=345.23\right.$ (56df) $\mathrm{p}=.008$; $\mathrm{GFI}=.997$; $\mathrm{CFI}=.990 ; \mathrm{NFI}=.995 ; \mathrm{RMSEA}=.009 ; \mathrm{RMR}=.007$ ] suggest the non-rejection of the null hypothesis regarding the differences between the competencies reviewed in the literature with respect to the structural model. 
Table 3: Descriptives of the CKD-28.

\begin{tabular}{|c|c|c|c|c|c|c|c|c|c|c|c|c|}
\hline $\mathbf{R}$ & $\mathbf{M}$ & D & yes & C & то & F1 & F2 & F3 & F4 & F5 & F6 & F7 \\
\hline R1 & 1.32 & ,821 & 1.59 & 1.54 & ,782 & & & & & & & ,360 \\
\hline R2 & 1.25 & .943 & 1.65 & 1.65 & ,793 & & & & & & & 469 \\
\hline R3 & 1.43 & .972 & 1.67 & 1.29 & ,784 & & & & & & & ,540 \\
\hline R4 & 1.39 & ,784 & 1.83 & 1.03 & ,763 & & & & & & & .457 \\
\hline R5 & 4.37 & 1.30 & 1.75 & 1.17 & ,751 & & & & & &, 564 & \\
\hline R6 & 4.21 & 1.21 & 1.60 & 1.81 & ,759 & & & & & & .439 & \\
\hline R7 & 4.21 & 1.43 & 1.73 & 1.43 & ,783 & & & & & & 406, & \\
\hline R8 & 4.43 & 1.46 & 1.83 & 1.12 & .752 & & & & & & .326 & \\
\hline R9 & 3.45 & 864 & 1.95 & 1.14 & ,714 & & & & & .435 & & \\
\hline R10 & 3.50 & .975 & 1.61 & 1.03 &, 750 & & & & & .329 & & \\
\hline R11 & 3.56 & ,931 & 1.68 & 1.05 & ,762 & & & & & .438 & & \\
\hline R12 & 3.52 & ,831 & 1.92 & 1.24 & ,741 & & & & & ,384 & & \\
\hline R13 & 1.39 & 4.36 & 1.61 & 1.16 & 739, & & & & .438 & & & \\
\hline R14 & 1.45 & 4.18 & 1.74 & 1.46 & .752 & & & & .548 & & & \\
\hline R15 & 1.46 & 4.39 & 1.82 & 1.67 & ,751 & & & & ,324 & & & \\
\hline R16 & 1.21 & 4.39 & 1.93 & 1.02 &, 754 & & & & .455 & & & \\
\hline R17 & 4.56 & 1.52 & 1.62 & 1.13 & ,749 & & & .421 & & & & \\
\hline R18 & 4.35 & 1.48 & 1.79 & 1.15 & ,731 & & & 486 & & & & \\
\hline R19 & 4.25 & 1.32 & 1.73 & 1.15 & ,743 & & & ,340 & & & & \\
\hline R20 & 4.67 & 1.14 & 1.82 & 1.45 & ,724 & & & ,389 & & & & \\
\hline R21 & 2.46 & 2.35 & 1.70 & 1.24 &, 743 & & ,398 & & & & & \\
\hline R22 & 2.57 & 2.14 & 1.82 & 1.13 & ,763 & & .412 & & & & & \\
\hline R23 & 2.54 & 2.43 & 1.71 & 1.15 & ,716 & &, 378 & & & & & \\
\hline R24 & 2.14 & 2.87 & 1.94 & 1.17 & ,730 & & ,420 & & & & & \\
\hline R25 & 4.50 & 871 & 1.84 & 1.06 & ,753 & .423 & & & & & & \\
\hline R26 & 4.67 & .943 & 1.74 & 1.09 & ,726 & ,379 & & & & & & \\
\hline R27 & 4.18 & 921 & 1.92 & 1.17 & ,743 & .421 & & & & & & \\
\hline R28 & 4.39 & .953 & 1.75 & 1.18 & ,750 & .347 & & & & & & \\
\hline
\end{tabular}

$\mathrm{R}=$ Reactive, $\mathrm{M}=\mathrm{Mean}, \mathrm{D}=$ Standard Deviation, $\mathrm{S}=$ Skew, $\mathrm{C}=$ Kurtosis, $\mathrm{A}=$ Alpha removing the value of the item. Adequacy $(\mathrm{KMO}=.732), \mathrm{Sphericity}[\mathrm{X}=23.6(5 \mathrm{df}) \mathrm{p}=.000 \mid$ Extraction method: principal axes, rotation: promax. F1=Accompaniment ( $18 \%$ of the total variance explained), F2=Adherence $(17 \%$ of the total variance explained), F3=Advice $(15 \%$ of the total variance explained), F4=Interview ( $13 \%$ of the total variance explained), F5=Mediation ( $11 \%$ of the total variance explained), F $6=$ Promotion $(8 \%$ of the total variance explained), F $7=$ Follow-up ( $5 \%$ of the total variance explained). All items are answered with one of five options: $0=$ "not at all likely" to $5=$ "quite likely".

Source: Self made.

\section{Discussion}

The present work has established the contrast of a model for the study of seven exploratory factorial dimensions of corporate reputation in HEIs in central, western and northern Mexico, although the type of non-experimental study, the type of intentional selection and the type of exploratory factor analysis limit the results to the study sample, suggesting lines of research and intervention related to the follow-up of cases as a factor reflecting the organizational phenomenon.

[1,3,19-28] contrasted models to observe corporate reputation in its reflective dimensions: 1) aversive or entrepreneurship and real innovation of the organization; 3) responsive or ecological footprint of the organizational production; 3 ) prospective or expected future of the organization, concluding that organizations seem to go through a process that goes from aversion to risks indicated by cultures, leaderships and adhocratic climates towards a propensity for the future indicated by cultures, leaderships and conciliatory climates of the organization image of collaborative knowledge networks.

In the present work, an exploratory model of seven factors has been contrasted in which the institutional follow-up of user cases is the hallmark of HEIs that, in alliance with health centers, train future operational-administrative cadres. The factor reflecting the follow-up of cases is part of the dimension of responsiveness cited in the literature.

Therefore, it is necessary to: a) build an instrument to explore the indicators of the responsive dimension as a preponderant factor of corporate reputation; b) contrast an exploratory model in order to establish the convergent and divergent validity of the scale; c) associate the responsive dimension with the aversive and prospective dimensions in order to build an integral model. 
Figure 2: Structural model of trajectories of dependency and reflective relationships.

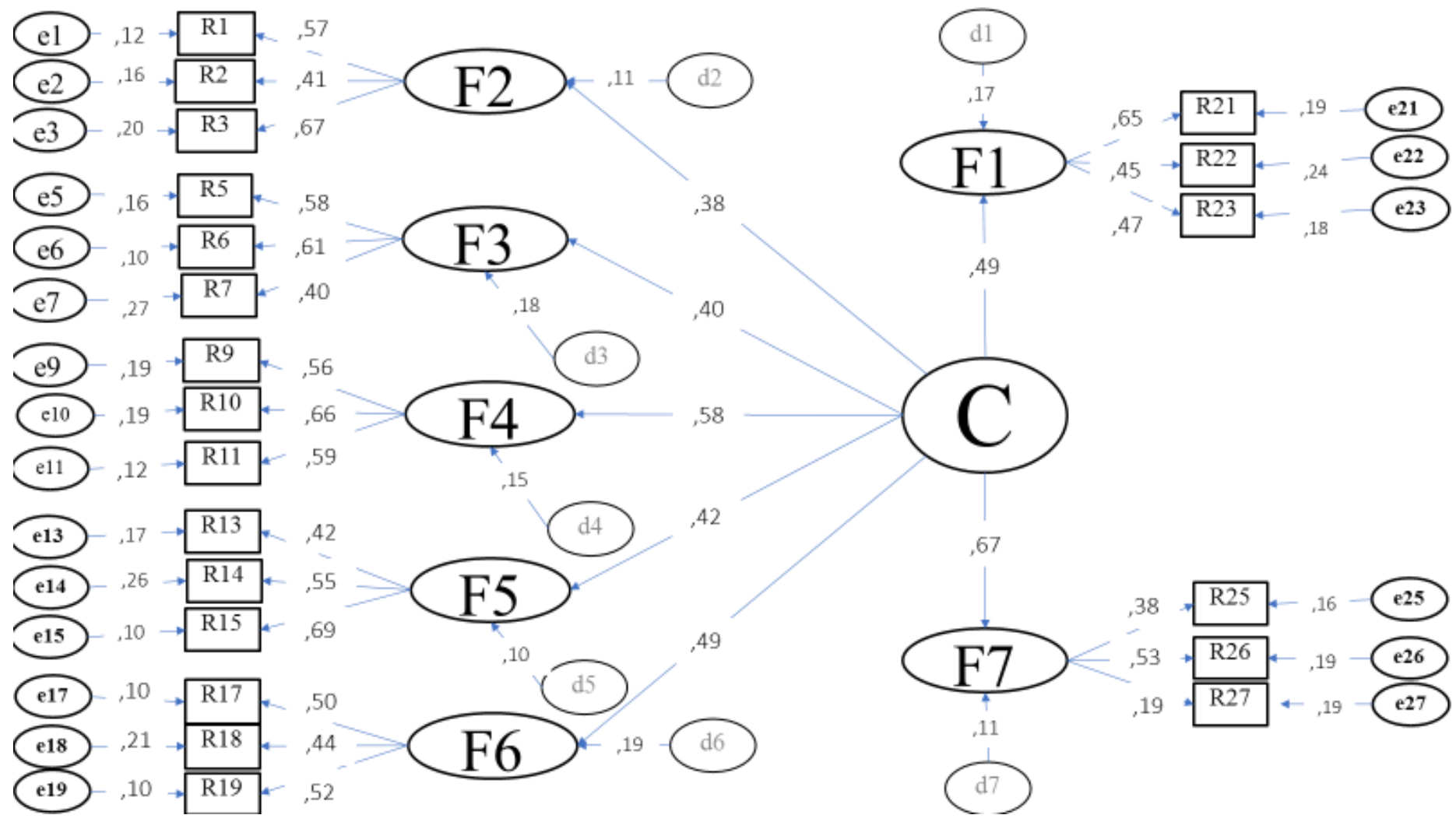

$\mathrm{C}=$ Corporate Reputation: F1 = Accompaniment, F2 = Adhesion, F3 = Advice, F4 = Interview, F5 = Mediation, F6 = Promotion, F7 = Follow-up; r = Reactive, $\mathrm{d}=\mathrm{Disturbance,} \mathrm{e}=\mathrm{Measurement}$ error Source: Prepared with study data.

\section{Conclusion}

The present work has contrasted a model of seven dimensions reflecting the reputation of HEIs specialized in Social Work in Health, which is centered on the competence of case follow-up. In relation to the findings reported in the literature, the model can be specified in the responsive dimension, this being the one that would explain the distance or closeness that the respondents refer to as the competitive advantage of their academic and professional training.

\section{References}

1. Bustos JM, Ganga F, Llamas B, Juárez M (2018) Contrast of a prospective decision model in implications for a university governance of sustainability. Margin 89: 1-16.

2. Garcia C (2018a) Reliability and validity of an instrument that measures knowledge management in a public university in central Mexico. Tlatemoani 27: 285-304.

3. Sánchez R, Villegas E, Sánchez A, Espinosa F, García C (2018) Model for the study of organizational clarity and corporate social responsibility. Synchrony 22: 467-483.

4. García C, Espinosa F, Carreón J (2018) Model of intangible assets and capitals in organizations. International Journal of Research in Humanities and Social Studies 5: 1-12.

5. Garcia C (2018b) Interpretations of knowledge management discourses for the understanding of narratives of innovative entrepreneurship. Inclusions 5: 96-111.

6. Garcia C, Martinez E, Rivera PE (2018) Labor flexibility in higher education. Inclusions 5: 51-69.

7. Villegas E, Garcia C, Hernandez TJ (2018) Establishment of a science and technology policy for the incubation of innovative knowledge micro-enterprises. Inclusions 5: $19-26$.

8. Rubio A, Jiménez IC, Mercado C (2017) Online corporate reputation in the hotel industry: The case of tripadvisor. Market Economic \& Business Journal 48: 579-593.
9. Perrini F, Vurro C (2013) Stakeholders orientation and corporate reputation: A quantitative study on US companies. Emerging Issues in Management 1: 53-65.

10. Babie V, Arslanagic M, Mehic E (2013) Importance of internal marketing for service companies' corporate reputation and customer satisfaction. Journal of Business Administration research 12: 49-57.

11. Barnnett M, Jermier JM, Lafferty BA (2006) Corporate reputation: The definitional landscape. Corporate Population Review 9: 26-38.

12. Blajer A (2014) Corporate reputation and economic performance the evidence from Poland. Economic \& Sociology 7: 194-207.

13. Cariton R, Moura RC (2012) The impact of R\&D intensity on corporate reputation interaction effect of motivation with high social benefit. Intangible Capital 8: 216-238.

14. Beheshtifar M, Korouki A (2013) Reputation: An important component of corporation value. International Journal of Academic Research in Business \& Social Science 3: 15-20.

15. Casimiro MC, Matos A (2017) The impact of corporate reputation in a dairy company. Business \& Economics Journal 8: 1-11.

16. Marquina P, Arellano R, Velázquez I (2014) A new approach for measuring corporate reputation. Administration 54: 53-66.

17. Martinez P, Rodriguez I (2013) Intellectual capital and relational capital: The role of sustainability in developing corporate reputation. Intangible Capital 9: 262-280.

18. Fiala R, Prokov M (2013) The relationships among reputation, inter-organizationa trust and alliance performance. University Act 99: 899-908.

19. Hernández TJ, Sánchez A, Espinosa F, Sánchez R, García C (2018) Model of lucidity, entrepreneurship and innovation in coffee microenterprises in central Mexico. Eureka 15: 96-107.

20. Garcia C, Rivera PE, Martinez E (2018) Institutionalist academic culture in Cuernavaca, Modelos (Mexico). Inclusions, 5: 84-96.

21. Garcia C, Rivera PE, Martinez E (2018) Institutionalist academic culture in Cuernavaca, Modelos (Mexico). Inclusions, 5: 84-96. 
22. Jinfeng L, Runtian J, Quian C (2014) Antecedents of corporate reputation and customer citizenship behavior. International Business \& Management 9: 128-132.

23. Kelinde $O$ (2012) Organizational culture and its corporate image: A model juxtaposition. Business \& Management Research 1: 121-132.

24. Kolade OJ, Olakkeke O, Omotayo O (2014) Organizational cityzenship behavior, hospital corporate image and performance. Journal of Competitiveness 6: 36-49.

25. Melero I, Lopez ML (2017) Identifying link between corporate social responsibility and reputation: Some considerations family firms. Journal Evolutionary Studies in Business 2: 191-230.
26. Olajide FS (2014) Corporate social responsibility practices and stakeholders expectations. Research in Business \& Management 1: 13-31.

27. Rondeau KV (2017) The impact of world ranking systems on graduate schools of business: promoting the manipulation of image over the management of substance. World Journal of Education 7: 62-73.

28. Cowboy A (2012) Online reputation in the framework of corporate communication. An insight into research trends and career prospects. Communication 3: 49-63.

\section{Citation:}

Carreón-Guillén J, Hernández-Gracia TJ, Sánchez-Sánchez A, Espinosa-Morales F, Fierro-Moreno E, et al. (2022) Corporate Reputation of the Schools and Faculties of Social Work around Training by Competences of Intellectual Capital. Ageing Sci Ment Health Stud Volume 6(1): 1-6. 